\title{
The Semantic Structures Of Balinese Verb: Mabersih ‘To Clean' Conveying Profane- Sacred Values
}

\author{
I Nengah Sudipa \\ English Department, Faculty of Arts Udayana University, Denpasar, Bali, Indonesia \\ E-mail: nengahsudipa@yahoo.co.id
}

Ni Made Suryati

Balinese language Department, Faculty of Arts Udayana University, Denpasar, Bali, Indonesia

E-mail: suryati.jirnaya@yahoo.com

Luh Putu Laksminy

English Department, Faculty of Arts Udayana University, Denpasar, Bali, Indonesia E-mail: luhputulaksminy@gmail.com

I Ketut Jirnaya

Old-classical Javanese Department, Faculty of Arts Udayana University, Denpasar, Bali, Indonesia

E-mail: jirnaya.suryati@yahoo.com

Received: February 4, 2018 Accepted: February 16, 2018 Published: August 15, 2018

doi:10.5296/ijl.v10i4.13508ＵRL: https://doi.org/10.5296/ijl.v10i4.13508

\begin{abstract}
There are a number of lexicons relating to the meaning of to clean translated into mabersih or nelain in Balinese language. The fact shows that such lexicons are not only used to express the daily routine activities in Bali-Indonesia, but also to accommodate various values. This article aims at describing the semantic structures of Balinese verbs in order to find out
\end{abstract}




\section{Macrothink}

International Journal of Linguistics

ISSN 1948-5425

2018, Vol. 10, No. 4

the profane and sacred values. The data was taken from daily conversations and Balinese texts as the written data. The oral data was collected through interview and the written ones by observation and note-taking. The collected data was analyzed by using the metalanguage approach, proposed by Allan (2001). The result showed that most of the encountered verbs being used are carrying profane nuance, among others: mandus, mambuh, masugi, mabaseh, masikat, nyampat, ngepél, ngumbah. Some lexicons are implying sacred values, as the lexicon ngingsah 'cleaning and washing rice' carries two possible values, both profane and sacred in certain activities done for the different purposes (a) rice for cooking daily food or (b) rice for making ritual ceremony substances. The lexicon malukat, mabayuh, and masapuh are used to express the nuance done by people to clean them spiritually.

Keywords: Profane, Sacred values, Ngingsah, Malukat 


\section{Introduction}

Balinese has three domains namely spoken, written and literary languages and is still used by Balinese speakers for daily activities in Bali, Sumbawa, West Lombok and other transmigration areas in Indonesia. As other natural languages, Balinese has phonological, morphological, syntactical and semantic fields to analyze. From the semantic point of view, Balinese lexicons are interesting to be reviewed, especially the verbs with to clean notion. Apart from having the respective lexical meanings, the verb variants dealing with to clean can convey not only the profane but the sacred nuances as well.

I Nengah Medera in his recent book entitled Tradisi Nyastra dan Seka Pesantian di Kota Denpasar 'Literary Tradition and Singer Group in Denpasar' (2017:7) said that in using refined Balinese language, the formula of logic, ethic and aesthetic values can be expressed. I Gede Samba (2016) in his book with title of HINDU, as a way of life, states that words in Balinese having speech levels indicating the religious value related to the way and status of the Hindu Balinese speakers when they are interacting each others. Moreover, Ngakan Made Madrasuta (2017), added in his famous publication Hindu Menjawab 3 'Hindhu Responds 3 ' that any sacred places in Bali become the destination of pilgrimage for people searching the life-balance, by washing all body, bathing and sprinkling holy water to cleansing them spiritually.

"In order to find more about the value conveyed by Balinese lexicons, it can be done, among other things by applying certain approaches to reveal the real meaning”. What is the appropriate approach to be used to reveal the meaning configuration of Balinese lexicon respectively? As Nicholas Asher, Tim Van de Cruys and Márta Abrusán, in their article entitled Lexical Semantics Today ( Allan, edited:2016:174), said

"In contrast to the sense enumeration model of word meaning is the view that lexical semantics consists of a set of lexical entries, supplemented with a set of maps from one lexical meaning to another”.

Through the procedures of mapping, this article is expected to manage giving more understanding about the value conveyed by the lexicons concerned.

\section{Methods}

The data of this article are from oral and written Balinese language. The oral one was collected from the Balinese spoken in two regencies, Buleleng and Klungkung. Buleleng is located in the North part of Bali having been decided as the region with standard Balinese (Balinese symposium Result 1979). Klungkung is the former famous Balinese kingdom center is supposed, for the society members still maintaining the standard Balinese nowadays. These two research locations are expected to represent the standard usages of Balinese language in Bali. The written data is from the weekly newspaper called Bali Orti (BO) published in 2017. This paper is specially issued in Balinese language dealing with: Balinese culture, literary works, current news, poems and short-story. The oral data was collected by direct interview with the key-informan in the respective research areas. The written one is by observation and note taking (Cargil, et al. 2013:37). The collected data was furthermore 
analyzed by metalanguage approach. According to the book entitled Words \& Meanings: Lexical Semantics across Domains Languages \& Cultures (Goddard and Weirzbicka, 2014: 10)

"any approach to describing the meanings of words must therefore recognize the fundamental importance of the metalanguage of description; in particular, it must ensure that the metalanguage issues is the exception rather than the rule in linguistics".

This approach turns out to give detail configuration about the semantic structure of action verbs to clean conveying the profane and sacred values. As stated by Allan (2001: 8) the language which a linguist uses to describe and analyze the object is called the metalanguage.

A metalanguage is just another language, often an artificial and not a natural one. One important practical constrain on a metalanguage is that (mostly) it needs to be understood by human beings who normally communicate in a natural language of which they have fluent command.

\section{Results}

The collected data was analyzed by using the approach of metalanguage, based upon the: entity, process, instrument and the result. The findings show that the action verb of Balinese language, meaning to clean conveys not only the daily general nuance, but also the religious one. The followings are the result showing the general meaning of to clean bringing the profane nuance. Profane (Hornby, 2000:1010) is not connected with religion or holy things, secular. The activities done by Balinese people and expressed by the following verbs are considered secular. They are cleaning the general items and the body with its parts.

\subsection{Cleaning the General Items}

(3-1) mabersih

\begin{tabular}{|c|c|c|c|c|c|}
\hline suud & mabersih & di kelas & tiang & maakin & Luh Sari (BO 18/6/2017:13) \\
\hline ГIME & clean & PREP class & PRO & come & NAME' \\
\hline
\end{tabular}

'after cleaning in the class I come closer Luh Sari'

The word mabersih is very general lexicon expressing the meaning of to clean. Almost all such general items can be cleaned and then expressed by this verb. The activity of to clean can be either supported by instrument or not. As the (3-1) suggests that the activity of to clean does not need any instrument, but merely bare-hands. The process how to clean is not only once, but repeated several times. The result that the class-room is tidy.

(3-2) nelain

$\begin{array}{ccccc}\text { I Bapa } & \text { nelain } & \text { mis } & \text { di malun } & \text { sanggah-é } \\ \text { NAME } & \text { clean } & \text { rubbih } & \text { PREP } & \text { shrine }- \text { DEF }\end{array}$

'Father clean rubbish in front of the shrine' 


\section{Macrothink Institute ${ }^{\mathrm{TM}}$}

The lexicon nelain suggests that the activity focusses on the disposals to be removed. The activity needs very much an instrumen, such as: duster or broom, and repeatedly done in order that the object is cleanly dismissed, until no more rubbish on the spot concerned.

(3-3) nampedang

$\begin{array}{lllll}\text { Liu ajak } & \text { nampedang } & \text { buku-né } & \text { suud } & \text { malajah } \\ \text { Many participant } & \text { clean } & \text { book-DEF } & \text { TIME } & \text { study }\end{array}$

'Many people clean (by putting in good order) the books after studying'

The word nampedang is appropriately used to express the combination activity of to clean and the put together in a good order, therefore the pile of the books is seen very tidy. The (3-3) illustrates that the books are well put orderly after the studying activity.

(3-4) milpilang

$\begin{array}{llllll}\text { Dagang-é } & \text { iteh } & \text { milpilang } & \text { don } & \text { lakar } & \text { adepa } \\ \text { Seller-DEF } & \text { busy } & \text { clean } & \text { leaf } & \text { to be } & \text { sold }\end{array}$

'The seller is busy to clean (by putting in order) leaves to be sold'

The item to be cleaned and tidied is usually in the form of a piece of paper, leaf or a flat thing. This activity is carefully and repeatedly done since the item is very tiny, thin and flat. The result is that the item looks very smartly tidy and well-ordered.

$$
\text { nyampat }
$$

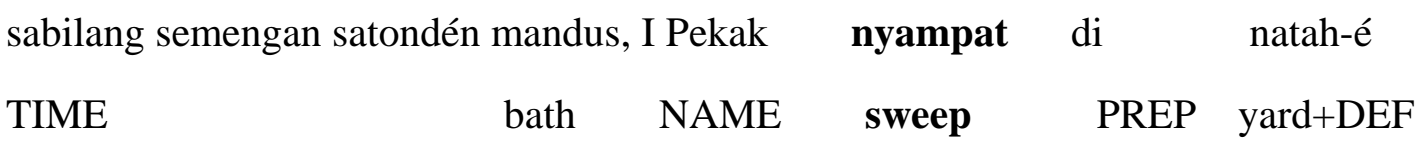

'Every morning, before taking a bath, grandfather sweep the yard'

This is very common action to clean the yard by sweeping, using broom to collect the rubbish and other earthy dirt. The lexicon nyampat indicates that the activity is done not once, nor twice but repeatedly, until the concerned location is clean, free from rubbish and other dirt.

(3-6) ngepél

$\begin{array}{llrrr}\text { selid sanja } & \text { I Wawan } & \text { ngepél } & \text { aji } & \text { superpel’ } \\ \text { Time } & \text { NAME } & \text { scrub } & \text { PREP } & \text { liquid }\end{array}$

'In the morning and afternoon I Wawan scrub (the floor) by the aromatic liquid'

This activity is usually done after the floor has been cleanly swept. The floor is the only entity used as the object of this activity. The instruments used to do this are a special tool and aromatic, disinfectant liquid to prevent it from the bacteria. This is a repeated action until the floor is clean, shiny and healthy for the members of the family in the house. This lexicon 
seems to be the modern Balinese one since using the liquid for the ceramic floor (Sudipa, 2015:24)

(3-7) ngumbah

$\begin{array}{lllllll}\text { Mara teka } & \text { uli } & \text { sekolah } & \text { ia } & \text { lantas } & \text { ngumbah } & \text { baju-né } \\ \text { TIME } & \text { PREP } & \text { school } & \text { PRO } & \text { then } & \text { wash } & \text { shirts-POSS }\end{array}$

'Soon arriving from school, he then washes his shirts'

The ngumbah activity as usual is done for shirts, shorts, skirts and other wears. The process is usually repeated until the items considered to be clean and ready to hang in the washing line.

(3-8) nyutsut

$\begin{array}{lllll}\text { Dija } & \text { ada } & \text { anak } & \text { nyutsut } & \text { motor ? } \\ \text { Q } & \text { be } & \text { PERSON } & \text { wash } & \text { motorbike }\end{array}$

'where is someone washing motorbike?'

This activity is specially designed for cleaning items such as: box, basket, motorbike and other domestic things. Apart from using wet-cloth, nyutsut needs also water and done repeatedly until the items are considered clean and dry.

(3-9) ngelap

$\begin{array}{llllll}\text { Adéng-adéng } & \text { ngelap } & \text { meja kaca, } & \text { apang } & \text { tusing } & \text { belah } \\ \text { Slowly } & \text { clean } & \text { table glass, } & \text { PREP } & \text { NEG } & \text { broken }\end{array}$

'Be slowly to clean the glass-table, in order not to be broken'

This Balinese daily activity expressed by ngelap is usually done to clean something free from ash, dust using dry-cloth. This activity is usually done only once and the items: table, chair, glass, etc. immediately becomes clean.

(3-10) ngabas

$\begin{array}{lllrrr}\text { nyén } & \text { bareng } & \text { ngabas } & \text { pagehan-ē } & \text { di } & \text { uma? } \\ \text { Q } & \text { participte } & \text { cut } & \text { fence-DEF } & \text { PREP } & \text { field }\end{array}$

'Who participates to clean (by cutting) the fences in the rice-field?'

The lexicon ngabas is specially used to express the cutting concept of the top-part of a tree, tip of tree-leaves in order to make it tidy and short. Ngabas is closely associated to express not only the cleaning activity but also conveying the concept of cutting. This is according to Weirzbicka (1996:27-29) called non compositional polysemy. This means that one lexicon can express two different semantic primes even when they are not having compositional 


\section{$\Lambda$ Macrothink}

International Journal of Linguistics

ISSN 1948-5425

2018, Vol. 10, No. 4

relationship between the components because they have different gramatical framewok respectively.

(3-11) ngelasin

$\begin{array}{llll}\text { dini tongos } & \text { melah } & \text { ngelasin } & \text { nyuh } \\ \text { LOC } & \text { good } & \text { clean } & \text { coconut }\end{array}$

'here is a good place to clean coconut'

The activity expressed by ngelasin is closely related to clean the skin, outer part of soft item: coconut, sweet patato, cucumber, mango, etc. This must be done carefully since it requires small, sharp knife. The result seems that the mango, for instance becomes clean after being peeled or taken the skin out of the fruit (Hornby, 2000: 934)

\subsection{Cleaning the Body and the Parts}

The following lexicons were found to have the concept of to clean, wash only the body or the parts of body as the entity of the cleansing activity.

(3-12) mandus

$\begin{array}{llcccc}\text { Ia } & \text { mandus } & \text { ping } & \text { duwa } & \text { a } & \text { wai } \\ \text { PRO } & \text { bath } & \text { TIME } & \text { NUMBER } & \text { ART } & \text { day }\end{array}$

'He/she takes a bath twice a day'

Taking a bath traditionally is still done in the public bathing place to wash the whole body. Before the soap was introduced, some people used stone to repeatedly rub the body in order to remove the body-dirt, then water the whole body thoroughly. In modern era, although most of Balinese people have already taken a bath in the bath-room, the lexicon mandus is still used with the additional feature with soap, stone, towel. (informan Buleleng)

(3-13) mambuh

$\begin{array}{lllcccc}\text { nganggo } & \text { shampoo } & \text { apa } & \text { cening } & \text { yén } & \text { mambuh } & \text { sedina-dina? } \\ \text { Use } & \text { THING } & \text { Q } & \text { PRO } & \text { if } & \text { wash } & \text { TIME }\end{array}$

'What shampoo do you use if you wash (hair) every day?'

The concept of cleansing for hair is absolutely expressed only by mambuh. From the metalanguage approach, if someone says 'mambuh' the hearer directly manages to map and associate the activity is dealing with washing hair, nothing else. In the traditional era, before shamppo liquid and hair-dryer were introduced, Balinese used to complete this activity by the traditional mixed herb and the process of washing the hair lasted very long around 2 hours until the hair clean and dry. (informan Klungkung)

(3-14) masugi

$$
\text { Cening masugi apang seger wiréh mara bangun }
$$


PRO clean to fresh because TIME wake- up

'You wash (face) in order to be fresh since (you) just get up

As in (3-13) this lexicon is also specially used for expressing the washing activity for face . The activity may use water and sometimes with soap. This activity is usually done not only once but more than twice and completed by the rubbing to make it dry by the towel.

(3-15) mabaseh

$\begin{array}{llcccc}\text { Makelo } & \text { anak-é } & \text { lingsir } & \text { mabaseh } & \text { di } & \text { tukad-é } \\ \text { TIME } & \text { PRO-DEF } & \text { NAME } & \text { wash } & \text { PREP } & \text { river-DEF }\end{array}$

'It takes time for the old man to wash (hand and leg) in the river'

The inherent concept of cleansing hand and leg/foot has been included and expressed automatically by the lexicon mabaseh. The other instrument used to complete the mapping of this meaning is water, because the activity of mabaseh can be properly mapped basically as cleaning by water only the hands, legs, and feet (not the other body’s parts).

(3-16) ngebeg

$\begin{array}{lllllll}\text { Lan tulungin } & \text { I dadong } & \text { ngebeg } & \text { tundun-né, } & \text { apang } & \text { enggal } & \text { kedas } \\ \text { Let help } & \text { NAME } & \text { clean } & \text { back-POSS, PREP } & \text { fast } & \text { dirt-less }\end{array}$

'Let us help the grandma clean (by rubbing repeatedly) her back in order to be soon dirt-less'

Two different semantic primes having no composition relationship between their components: clean and rub (Weirzbicka, 1996:27-29) are accommodated by the single lexicon ngebeg. It can be mapped that someone does the activity of to clean by washing and rubbing the part of the body in order to remove the dirt. This is, of course done more than once to get the clean result of the body itself.

(3-17) ngusap

$\begin{array}{llll}\text { Mén Semari } & \text { ngusap } & \text { yéh } & \text { paningalan-né (BO 11/6/2017:13) } \\ \text { NAME } & \text { clean } & \text { water } & \text { eyes -POSS }\end{array}$

'Mrs Semari clean (slowly and repeatedly) her tears

This activity only happens around the face including eye, cheek, chin, nose only. The doer usually uses bare hand or handkerchief, cloth, cotton to clean and dry the location. Since this is located in the face, soft and slow motion are required to rub or remove the tears, the dust and other bad-spots.

(3-18) makemuh
dini mé
makemuh
apang
tusing
belus
natah-é 
LOC NAME clean

PREP

NEG

wet

floor-DEF

'Here Mum clean and wash (your mouth) in order not to wet the floor'

The lexicon makemuh is only used to express the cleaning of mouth by water. The mother (3-18) who usually after having a big meal wants to clean her mouth, takes a glass of water and put only in the mouth cavity. She moves her tongue around and around the cavity and teeth, and ultimately vomit the dirty water out of the mouth without being swallowed.

(3-19) masikat

$\begin{array}{lcccccr}\text { Ping telu } & \text { awai } & \text { I Sora } & \text { masikat } & \text { sesuban } & \text { suud } & \text { medaar } \\ \text { NUMBER } & \text { TIME } & \text { NAME } & \text { clean } & \text { PREP } & \text { finish } & \text { eating }\end{array}$

'Three times a day Ms Sora clean (her teeth by tooth-brush) after having meal'

The lexicon masikat has the root of sikat 'brush', the prefix ma- forms Noun into Verb meaning to brush. There are two meanings in Balinese of the verb masikat (1) brushing the teeth and (2) brushing the shoes. The most popular one, without being related to the context, if it is used in the short sentence: suba masikat? it will mean '(have you) already brushed your teeth?'. This lexicon can be mapped that the activity must be completed by the only instrument sikat 'a tooth-brush' and repeatedly done until the teeth are absolutely white and clean.

\section{Discussion}

\subsection{Profane and Sacred}

It goes without saying that a lot of lexicons in local language may carry inherent meaning in its form, like masugi 'washing face', masikat 'cleaning teeth' and here is ngingsah automatically means washing rice. The only finding of Balinese lexicon ngingsah can show two perspectives, namely profane and sacred. Such perspectives are ideally related to the contexts of situation: culture, religion and tradition in Bali (Samba,2016:67). The daily activity of Balinese people when they wash the rice for cooking must be classified having the profane nuance.

(4-1) ngingsah

\section{Nyén ngingsah?}

Q wash

'Who washed the rice for cooking?'

The above example (4-1) indicates that according to the Balinese tradition, the question is asked for getting the daily respond. As it is translated as: wash the rice for cooking conveys the profane perspective since it is only related to their daily routine.

Apart from carrying profane nuance, the lexicon ngingsah in the context of religion and culture, especially in preparing the ritual ceremony, as data (4-2) the activity of washing rice 
is usually done. Balinese Hindu people implements five kinds of ceremonies, called yadnya (Samba, 2016:112) along their life, namely (1) Dewa Yadnya, rite for God, (2) Pitra Yadnya, for Ancestors, (3) Rsi Yadnya, for Guru, teachers, trainers, (4) Manusa Yadnya, for Human beings and (5) Bhuta Yadnya, for environments. These ritual ceremonies need some preparation including substances from flower, fruit, water, fire and rice. In preparing cake from rice for instance, the rice must be spiritually washed based upon the good day to wash it, the holy place to do the washing and the person in charged must be spiritually holy (informan: Klungkung)

(4-2) ngingsah

$\begin{array}{lllllll}\text { Yén } & \text { ngaé } & \text { banten-odalan, } & \text { mesti } & \text { ngingsah } & \text { di tongos } & \text { suci } \\ \text { CONDITIONAL make } & \text { offering rite, } & \text { must } & \text { wash } & \text { PREP LOC } & \text { holy }\end{array}$

'If making ritual offering, washing (rice) must be in the holy place'

(Medera, 2017:7)

\subsection{Sacred}

The lexicons: malukat, mabayuh and masapuh conveying sacred nuances were found during the research conducted in 2017 in two regencies, Buleleng and Klungkung (Sudipa, 2017). The semantic structures of these three lexicons can be proved by mapping the meaning configuration, having spiritual value, or sacred nuance. Sacred, according to Hornby (2000:1126) is always connected with God or a god, considered to be holy.

(4-3) malukat

$\begin{array}{ccccc}\text { (a) Satondén } & \text { maturang } & \text { bhakti, } & \text { malukat } & \text { malu } \\ \text { TIME } & \text { offer } & \text { pray, } & \text { wash } & \text { first }\end{array}$

'Before doing the pray, clean (spritually by sprinkling holy water) first

This activity is usually conducted by sprinkling holy-water to all the persons who will pray in order to clean themselves spiritually. After the holy water being sprinkled by the priest assistans, the followers feel clean and ready to worship the God.

$\begin{array}{rlllll}\text { (b) Liu } & \text { jani } & \text { anak-é } & \text { malukat } & \text { di } & \text { Tampaksiring } \\ \text { NUMBER } & \text { TIME } & \text { person-DEF } & \text { clean } & \text { PREP } & \text { LOC }\end{array}$

'Many people now clean (themselves spiritually by bathing) in Tampaksiring'

The meaning configuration of malukat can also be seen as an activity conducted by taking a bath, washing the head, hair in a certain holy places, holy river, temples or home of the priest (Samba, 2016) . The purpose of malukat is basically to feel holy and clean spiritually for the followers and ready to accelerate the further religious, spiritual activities such as to be priest assistants, traditional healers and fortune tellers.

(4-4) mabayuh 
Risampun wusan mabayuh, surudanné kajeng olih sang sané kabayuh (BO 16/7/2017:7)

TIME wash, SOMETHING be eaten

PREP PERSON

'After finishing the cleansing (ceremony), the rest of the offering is eaten by the person who is just cleaned spiritually'

This activity does not need water to clean someone spiritually, the instrument is usually a set of certain offering (Samba, 2016:87). The procession is usually witnessed by the family members only because the purpose of the ceremony is to free the concerned person spiritually from mental problems, endless sickness, and other serious life-sufferings. This activity may be conducted in the priest home, in the holy temple, or places chosen by the person concerned. The priest usually leads the ritual-ceremony and the person to be cleaned spiritually only obeys and follows what the priest says.

(4-5) masapuh

telu wai suud ngabén, anak-é pasti masapuh

TIME PREP cremation, person must do the cleansing

'three days after the cremation ceremony, people must clean (spiritually)

The lexicon masapuh is only referred to express the cleaning process for mental problems, usually after having bad events: death or cremation. This is sometimes called a special ceremony conducted within three or five days after the bad event. The purpose of this ceremony is to free the members from mental dirt. If the members are still suffering from 'mental dirt due to the death', they are not allowed to enter the temple, doing temple ceremonies nor actively participating in other holy rites. (Madrasuta, 2017:229)

\section{Conclusion}

The semantic structure of the verb to clean in Balinese approched by metalanguage manages to reflect the profane and sacred values. The lexicon mabersih bring the meaning of (a) tidying: magampil, nampedang, (b) washing: mambuh, makemuh; (c) clean by sweeping, scrubing: nyampat, ngepél; (d) clean by cutting: ngabas. These all refer to general activity of Balinese people referred to as profane nuance. The lexicon ngingsah brings two perspectives: profane and sacred depending on the context of usage. And three are outstanding encoutered lexicons conveying sacred value: malukat, mabayuh and masapuh.

\section{Acknowedgements}

We would like to thank to the Udayana University Rector for granting us to do the research in two regencies in Bali, and also our owes are due to the Dean of Faculty of Arts for enabling us to write this article for an International Journal.

\section{References}

Allan, K. (2001). Natural Language Semantics. Great Britain: Blackwell Publisher 
Allan, K. (ed.) (2016). The Routledge Handbook of Linguistics. New York: Routledge

Asher, N. (2016). Tim Van de Cruys dan Márta Abrusán. 2016. "Lexical Semantics Today” (in Allan, (ed) pp. 174)

Cargil, M., \& Patrick, O. C. (2013). Writing Scientific Research Articles, second edition. Oxford: Wiley-Blackwell.

Creswell, J. W. (2009). Research Design: Qualititive, Quantitattive, and Mixed Methods Aproaches, third edition. London: SAGE Publication, Inc.

Dasopang, A. F. (2017). Semantic and Semiotic Analysis of 'Rere Mana Rere' Song in the Culture of Mandailing. Macrolink, 9(3), published 4 June 2017

Goddard, C., \& Anna, W. (2014). Words \& Meanings: Lexical Semantics across Domains, Langugaes \& Cultures. Oxford: Oxford University Press.

Goddard, C., \& Anna, W. (2015). The Natural Semantic Metalanguage Approach. Oxford.

Hornby, A. S. (2000). Oxford Advanced Learner's Dictionary of Current English. Oxford: Oxford University Press.

Madrasuta, N. M. (2017). Hindu Menjawab 3. Jakarta Timur: Media Hindu.

Medera, I. N. (2017). Tradisi Nyastra dan Seka Pesantian di Kota Denpasar. Denpasar: Dinas Kebudayaan Kota Denpasar.

Samba, I. G. (2016). Mengenalkan Hindu: A way of life. Bandung: Yayasan Dajan Rurung Indonesia.

Source of Written data: BO (Bali Orti, a weekly local newspaper in Balinese language)

Sudipa, I. N. (2015). Buku Panduan Verba Bahasa Bali: Makna dan Penggunaannya. Denpasar ISBN ISBN 978-602-7599-23-9

Sudipa, I. N., Ni Made Suryati, Dewa Ayu Carma Citrawati, Dewa Ayu Carma Miradayanti dan Made Henra Dwikaramawan Sudipa. (2017). Struktur Semantik Verba Membersihkan Bahasa Bali: Pendekatan Metabahasa Semantik Alami. Hasil Penelitian Hibah Grup Riset Univ Udayana (unpublished)

Weirzbicka, A. (1979). Balinese Symposium Result.

Weirzbicka, A. (1996). Semantics: Primes and Universal. Oxford: Oxford University Press. 


\section{$\triangle$ Macrothink}

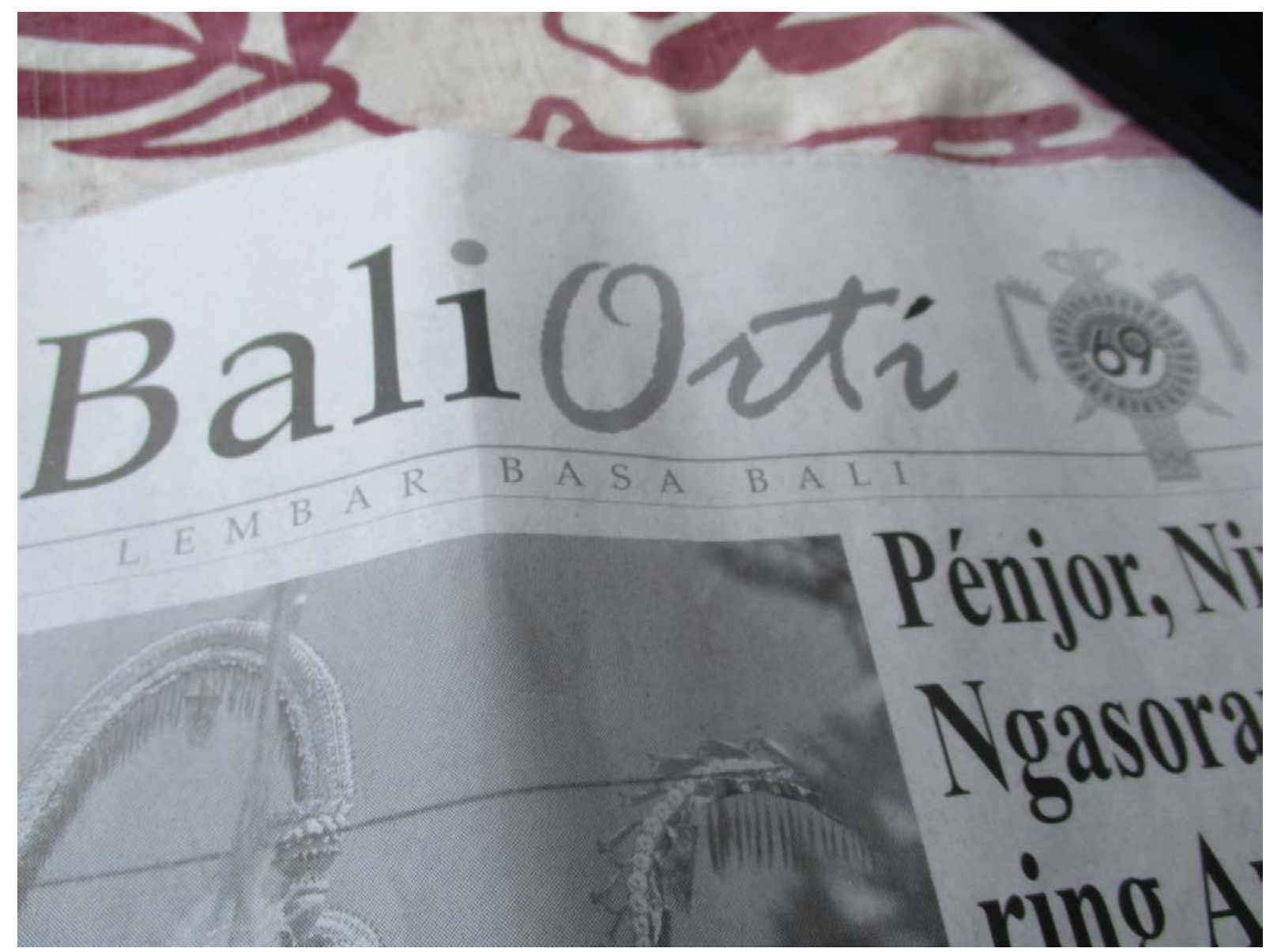

\section{Key Informan:}

In Buleleng (north Bali regency)

In Klungkung (south Bali regency)

\section{Copyrights}

Copyright for this article is retained by the author(s), with first publication rights granted to the journal.

This is an open-access article distributed under the terms and conditions of the Creative Commons Attribution license (http://creativecommons.org/licenses/by/4.0/) 